Review

\title{
Are Multiple Chemosensory Systems Accountable for COVID-19 Outcome?
}

\author{
Antonio Caretta ${ }^{1,2}$ (D) and Carla Mucignat-Caretta $2,3, *$ (D) \\ 1 Department of Food and Drug Science, University of Parma, 43100 Parma, Italy; antonio.caretta@unipr.it \\ 2 NIBB-National Institute for Biostructures and Biosystems, 00136 Rome, Italy \\ 3 Department of Molecular Medicine, University of Padova, 35131 Padova, Italy \\ * Correspondence: carla.mucignat@unipd.it; Tel.: +39-049-827-5304
}

Citation: Caretta, A.; Mucignat-

Caretta, C. Are Multiple

Chemosensory Systems Accountable for COVID-19 Outcome? J. Clin. Med. 2021, 10, 5601. https://doi.org/

$10.3390 /$ jcm10235601

Academic Editor: Vito Racanelli

Received: 24 October 2021

Accepted: 27 November 2021

Published: 28 November 2021

Publisher's Note: MDPI stays neutral with regard to jurisdictional claims in published maps and institutional affiliations.

Copyright: (c) 2021 by the authors. Licensee MDPI, Basel, Switzerland. This article is an open access article distributed under the terms and conditions of the Creative Commons Attribution (CC BY) license (https:/ / creativecommons.org/licenses/by/ $4.0 /)$.

\begin{abstract}
Chemosensory systems (olfaction, taste, trigeminus nerve, solitary chemoreceptor cells, neuroendocrine pulmonary cells, and carotid body, etc.) detect molecules outside or inside our body and may share common molecular markers. In addition to the impairment of taste and olfaction, the detection of the internal chemical environment may also be incapacitated by COVID-19. If this is the case, different consequences can be expected. (1) In some patients, hypoxia does not trigger distressing dyspnea ("silent" hypoxia): Long-term follow-up may determine whether silent hypoxia is related to malfunctioning of carotid body chemoreceptors. Moreover, taste/olfaction and oxygen chemoreceptors may be hit simultaneously: Testing olfaction, taste, and oxygen chemoreceptor functions in the early stages of COVID-19 allows one to unravel their connections and trace the recovery path. (2) Solitary chemosensory cells are also involved in the regulation of the innate mucosal immune response: If these cells are affected in some COVID-19 patients, the mucosal innate immune response would be dysregulated, opening one up to massive infection, thus explaining why COVID-19 has lethal consequences in some patients. Similar to taste and olfaction, oxygen chemosensory function can be easily tested with a non-invasive procedure in humans, while functional tests for solitary chemosensory or pulmonary neuroendocrine cells are not available, and autoptic investigation is required to ascertain their involvement.
\end{abstract}

Keywords: SARS-CoV-2; COVID-19; olfaction; taste; carotid body; oxygen sensing

\section{Introduction}

In order to survive, our body monitors the external and internal environment by detecting molecules through specialized receptors. The perception of external molecules mainly occurs through olfaction, taste, and trigeminal chemesthesis, which is the chemical sense mediated by the trigeminal nerve. These chemical senses have gained popularity for their involvement in interactions with the external environment during many daily activities, from food search/consumption to mate recognition, and started to gain popularity with the 2004 Nobel prize awarded to Buck and Axel for the discovery of olfactory receptors [1]. However, chemical signaling inside our body is also crucial for survival: Internal chemical sensing relies on receptors for oxygen, carbon dioxide, $\mathrm{pH}$ (hydrogen ions), plus several other molecules, such as glucose, fatty acids, and mediators of inflammation among others, that are present at many sites. These receptors are always active to monitor biochemical properties of the "milieu interieur" for maintaining homeostasis balance.

Traditionally, chemoreception was investigated by completely separated fields of research, pertaining to the perception of external (e.g., taste, olfaction) or sensing of internal chemical stimuli (e.g., respiratory gases, $\mathrm{pH}$ ). However, it is apparent that a clear-cut distinction between conscious and unconscious perception is not tenable, since each chemosensory system is not exclusively tuned to selected molecules, as was thought until a few decades ago. In actuality, chemosensory mechanisms hosted in different organs may be considered polymodal sensory systems that share some sensing molecules and transduction 
pathways. Olfactory neurons bear olfactory receptor proteins, yet they also express other receptors, for example, trace amine-associated receptors (TAARS) [2] and many receptors for hormones, to a large extent involved in metabolic regulation [3-5], but not limited to this function [6]. On the other hand, olfactory receptors are "ectopically" expressed at many sites [7] and contribute to various functions: In the pancreas, they modulate insulin release [8] and one olfactory receptor is involved in glucose metabolism [9]. Taste receptor cells, in addition to taste stimuli, are activated by inflammation mediators [10] and are sensitive to hormones that control metabolism, contributing to the regulation of food intake [4]. Similarly, chemosensory cells sensitive to internal signals are not narrowly tuned as previously alleged. For example, carotid body cells are sensitive to blood gases but also to glucose [11] and inflammatory mediators [12,13]; solitary chemoreceptor cells recognize microbial chemosignals [14] but also express sweet taste receptors that modulate the antimicrobial response [15]; pulmonary neuroendocrine cells can sense oxygen, carbon dioxide, and other different molecules, and are involved in ventilatory function and immunomodulation [16-18]; in the gastrointestinal tract, solitary chemoreceptor cells (aka tuft cells) recognize different microbial signals [19] while enterochromaffin cells also recognize glucose among other molecules [20].

All these chemosensory systems share common fundamental molecular markers: Carotid body cells, enterochromaffin cells, and pulmonary neuroendocrine cells express canonical olfactory receptors [21-23] and solitary chemosensory cells express canonical taste receptors [14]. Moreover, all the afferent signals of these chemosensory systems are clearly separated in the periphery, but in the central nervous system, they surprisingly converge on the same brain areas of the brainstem, subcortical, and cortical areas.

It is thus reasonable to assume that these chemosensory systems may also share a common sensitivity to the SARS-CoV-2 virus, given their similar molecular machinery. This idea is also supported by the fact that their function may be altered in COVID-19.

COVID-19 has been extensively studied since the beginning of the pandemic. A puzzling symptom of COVID-19 is the frequent impairment and even loss of taste and olfaction, reported by patients and/or clinically tested [24-26], that may resolve within days or weeks, but in some cases persists after months [27]. These chemosensory deficits are not specific to COVID-19 and have also been reported for other diseases, including viral infections [28], neurodevelopmental [29] and neurodegenerative disorders [30], cancer independently from treatments [31], metabolic diseases [32], and hypertension [33].

In the face of life-threatening pneumonia, taste/olfaction involvement is usually considered a minor problem by caregivers. In clinics, this inference may be presumably correct, because by themselves these symptoms are not lethal and, in most patients, they are transient [34]. Recently, attention has been paid to olfactory and taste systems in the light of the so-called LONG-COVID, the long-term consequences of COVID-19 [35], as the potential entry site of the virus to the brain and/or as a potential predictor of long-term brain damage or functional impairment.

The phenomenon named silent hypoxia refers to the lack of respiratory response (called dyspnea) to a life-threatening decrease in oxygen saturation of hemoglobin [36]. Several COVID-19 patients, either post-pneumonia or not, display silent hypoxia, since they fail to report any distress when in short of oxygen, for example after a brief physical exercise [36]. A major player in detecting oxygen levels in the blood is the carotid body, whose chemosensory function was postulated nearly a century ago [37]. In addition to the carotid body, an oxygen-sensitive potassium channel is present in neuroepithelial bodies/neuroendocrine cells in the lung, which may help in monitoring oxygen levels [38]. In COVID-19 patients, immune responses appear also deregulated. The solitary chemosensory cells (SCC) are a different class of chemoreceptors, known as gut tuft cells or airway brush cells [39,40]. Interestingly, they may also play a role in triggering immune responses [41]. Hence, it would be interesting to explore the role of different chemoreceptors in eliciting some yet unexplained COVID-19 symptoms. 


\section{A Hypothesis on Chemosensory Involvement in COVID-19}

It is suggested that, in addition to taste, olfaction, and trigeminal chemesthesis, other chemoreceptor cells (for example, carotid body chemoreceptors and solitary chemoreceptors cells) may be affected by COVID-19, with potentially dire consequences for patients. This hypothesis links the different chemosensory systems as possible targets of SARS-CoV-2. It gives rise to separate predictions that can be tested in the field, as detailed below.

\subsection{Testing the Hypothesis}

\subsubsection{Silent Hypoxia as a Test Case}

When COVID-19 results in acute respiratory distress syndrome (ARDS), some patients may experience the so-called "Silent Hypoxia": They show a life-threatening drop in hemoglobin oxygen saturation, despite being unaware of their oxygen shortage, that usually would trigger severe dyspnea [42]. These patients are deprived of a crucial alerting mechanism that drives the ventilatory responses and conscious behavior to counteract dangerous hypoxia. Its deficiency causes a delay in seeking proper treatment, with possible negative outcomes for patients' health. This failure may persist in ARDS survivors [43].

Several explanations for silent hypoxia mechanisms have been proposed:

1. The lack of hypoxic pulmonary vasoconstriction (HPV) [44,45].

2. A possible inflammation of the central nervous system at various levels and with different mechanisms [46-49].

3. The dysregulation of the renin-angiotensin system [50].

4. It has been proposed that the oxygen chemoreceptor function may have been impaired [51,52].

5. Lastly, it has also been suggested that COVID-19 silent hypoxia is not surprising and may be referred to as normal neurophysiological mechanisms [36,53].

No evidence is available to rule out or accept these different hypotheses, but the simplest explanation resides in the impairment of oxygen chemoreceptor cell function, mainly but not exclusively hosted in carotid bodies. Failure of these oxygen chemoreceptors could explain the absence of dyspnea as well as the absence of hyperpnea or polypnea. Moreover, the failure of pulmonary oxygen chemoreceptor cells/neuroepithelial bodies might explain the absence of hypoxic pulmonary vasoconstriction.

The possibility that damage to respiratory gas sensing and of taste/olfaction/trigeminal chemesthesis is tightly related is suggested by observations highlighting some challenging analogies between them:

- Anatomically, all of them host sustentacular cells, crucial for receptor cell survival and key entry sites for SARS-CoV-2. Moreover, stem cells are present in each organ, allowing cell turnover [54], which may drive the path to recovery.

- Afferents from the carotid body and from the posterior third of the tongue run together in the glossopharyngeal nerve through the petrosal ganglion to reach the solitary tract nucleus [55], targeting partially overlapping areas in the brainstem.

- Functionally, in taste buds, there are receptors sensitive to $\mathrm{pH}$ (sour taste receptors) that act similarly to ectopic chemoreceptors present in the larynx [56] and, most interestingly, in the carotid body [57].

- Receptors for carbon dioxide are also present in the olfactory mucosa [58] and in the mouth [59].

- Both the olfactory bulb and the carotid body host a large number of dopaminergic cells [60].

Interestingly, canonical olfactory receptor proteins, typical of olfactory mucosa, are expressed "ectopically" in carotid body cells and may trigger the hypoxic ventilatory responses, contributing to the maintenance of oxygen balance by controlling breathing when oxygen levels fall, a mechanism that relies on the carotid body [23,61]. Moreover, canonical olfactory receptors are present in pulmonary neuroendocrine cells, a class of polymodal sensors, also involved in oxygen sensing [22]. 
In all these chemoreceptor systems, ACE2 receptors are present and warrant the entry of SARS-CoV2 [62,63]. Moreover, in one patient, SARS-CoV2 was detected in the carotid body at autopsy [64].

For these reasons, we suggest that the hypothesis stated above can be split in two testable predictions, which can be validated (see Table 1):

1. Silent hypoxia is related to the malfunctioning of chemosensory cells, mainly carotid body chemoreceptors.

2. Taste and olfactory chemoreceptor cells are likely to be affected by the virus, together with carotid body chemoreceptors. Hence, taste and olfaction malfunction can be exploited as predictors of silent hypoxia. At present, no observation is available on the co-occurrence of these different chemosensory deficits, yet this hypothesis can be experimentally tested in a non-invasive way, as detailed in Table 1.

In the case of a person (Table 1, case 1) with normal taste/olfaction, normal hypoxic ventilatory response, and no silent hypoxia, nothing can be concluded about the abovementioned hypotheses. In the case of silent hypoxia with otherwise normal responses (case 2), it can be concluded that silent hypoxia does not depend on carotid body malfunctioning because of the presence of a normal hypoxic ventilatory response, while hypothesis II cannot be tested because taste, olfaction, and the carotid body are functioning correctly. Case 3 shows impaired carotid body functions with hypoxic ventilatory responses of which the patient is aware (no silent hypoxia), hence hypothesis I is falsified because the carotid body is not functioning while silent hypoxia is absent; also, hypothesis II is falsified because taste and olfaction are working, and carotid bodies are not. Case 4 has silent hypoxia and an impaired hypoxic ventilatory response, resulting in the verification of hypothesis I because carotid body impairment and silent hypoxia co-occur, while hypothesis II is falsified, because taste and olfaction are functioning while carotid bodies are not. Case 5 is a patient with only smell/taste disorders: In this case, hypothesis I cannot be tested because of the absence of both silent hypoxia and altered ventilatory response, while hypothesis II can be rejected because taste/olfaction are impaired while carotid bodies are functioning. If silent hypoxia is present together with smell/taste impairments but with a normal hypoxic ventilatory response (case 6), both hypotheses are falsified: Hypoxic response is present, hence carotid bodies are functioning, but silent hypoxia is present (hypothesis I), while taste/olfaction are impaired while the carotid body is functioning (hypothesis II). Case 7 is a patient with smell/taste disorders and altered hypoxic ventilatory responses, but without silent hypoxia: In this case, hypothesis I is falsified because of the absence of silent hypoxia, while hypothesis II is verified because of the co-occurrence of taste/smell disorders and carotid body impairments. In case 8 , all the responses are abnormal, which verifies both hypotheses because of the impairment of carotid body functioning in the presence of silent hypoxia and taste/smell disorders.

\subsubsection{Involvement of Solitary Chemoreceptor Cells}

Solitary chemosensory cells, also known as tuft cells in the gut or brush cells in airways, are a diffuse system of chemoreceptor cells. Although still commonly considered a marginal field of research both in physiology and immunology, in the last decade, new interesting data have been collected: These cells express the complex molecular machinery of taste chemoreceptor cells, and detect bitter and, to a lesser extent, sweet molecules $[14,65,66]$. Both on respiratory mucosa and intestinal mucosa they are known to trigger a mucosal innate immune response [67]. In addition, on respiratory mucosa, these chemosensory cells have been shown to contribute to breath control by activating afferent nervous fibers $[68,69]$. It is worth considering that persons that do not express taste receptor T2R38 have a worse prognosis if affected by COVID-19 [70], even if it is unclear whether this receptor is lacking in the tongue only or throughout the body. T2R38 is a bitter taste receptor initially found in the tongue, but also in the upper respiratory tract, where it may detect substances produced by Gram-negative bacteria, leading to the killing of bacteria and mucus clearance [71]. 
Table 1. A synopsis of the possible findings in patients, at diagnosis.

\begin{tabular}{lccccc}
\hline & $\begin{array}{c}\text { Taste/Olfaction } \\
\text { Tests }\end{array}$ & $\begin{array}{c}\text { Hypoxic Ventilatory } \\
\text { Response }\end{array}$ & $\begin{array}{c}\text { Silent } \\
\text { Hypoxia }\end{array}$ & $\begin{array}{c}\text { Hypothesis I } \\
\text { Silent Hypoxia Depends } \\
\text { on Carotid Body }\end{array}$ & $\begin{array}{c}\text { Hypothesis II Carotid Body and } \\
\text { Taste/Olfaction Chemoreceptors } \\
\text { Are Affected Together }\end{array}$ \\
\hline 1. & Normal & Normal & Absent & Not falsified, not verified & Not falsified, not verified \\
\hline 2. & Normal & Normal & Present & $\begin{array}{c}\text { Falsified. Silent hypoxia } \\
\text { not dependent on carotid } \\
\text { body functioning }\end{array}$ & Not falsified, not verified \\
\hline 3. & Normal & Not normal & Absent & $\begin{array}{c}\text { Falsified. Hypoxia } \\
\text { dependent on carotid } \\
\text { body functioning. }\end{array}$ & Falsified \\
\hline 4. & Normal & Not normal & Present & Verified & Falsified \\
\hline 5. & Not normal & Normal & Absent & Not falsified, not verified. & Falsified \\
\hline 6. & Not normal & Normal & Present & Falsified & Falsified \\
\hline 7. & Not normal & Not normal & Absent & Falsified & Verified \\
\hline 8. & Not normal & Not normal & Present & Verified & Verified \\
\hline
\end{tabular}

In bold: Pathological findings. * At least one not-normal value is sufficient for inclusion in the "not normal" group

At present, no information is available on solitary chemosensory cells in COVID-19 patients. We suggest that the loss of function of solitary chemosensory cells may jeopardize the mucosal innate immune response, thus paving the way to a devastating entry of a large amount of virus particles. This may explain why the course of this disease is quite different among patients, ranging from asymptomatic infection to death.

The innate response mediated by solitary chemoreceptor cells is demonstrated in respiratory mucosa only for bacteria [14]. It is unknown whether solitary chemosensory cells express the ACE2 receptor, but it is not necessary that chemosensory cells are directly destroyed by the virus, since the loss of function can be achieved by the damage of nearby cells, similarly to SARS-CoV-2 action in the olfactory mucosa [72].

At present, the solitary chemoreceptor cell function cannot be clinically examined in patients, yet this system should be investigated post-mortem. The possibility of exploring this issue in animal models remains open.

Lastly, a diffuse impairment of chemosensory systems may also explain the worsening of metabolic regulation and the inflammatory response in already compromised, fragile patients.

\section{Conclusions}

We suggest that, while apparently different for structure, location, intracellular signaling, and sensitivity, the shared molecular signature of the different chemoreceptor systems may underlie common SARS-CoV-2 vulnerability.

From a clinical perspective, we propose that, starting in the early stages of infection on an outpatient basis, it may be worth measuring olfaction and taste functions, with simple tests or surveys $[26,27,73-75]$ together with the oxygen chemoreceptor response using the Transient Test for Hypoxic Ventilatory Response [76,77] and six-minute walking test $[78,79]$. In this way, it would be possible to understand if the impairment of taste and olfaction correlates with carotid body chemoreceptor impairment and silent hypoxia (see Table 1) and if it is possible to predict which patients are at risk of silent hypoxia, notwithstanding the fact that the actual degree of involvement of each chemosensory system may differ in each person.

Lastly, we suggest that in COVID-19 patients, genetic or functional analysis of bitter taste receptors as well as, unfortunately under the present circumstances, systematic autoptic investigations of chemosensory systems, is warranted. 
Author Contributions: Conceptualization, formal analysis, investigation, writing-original draft preparation, writing-review and editing: A.C. and C.M.-C. Supervision and funding acquisition: C.M.-C. All authors have read and agreed to the published version of the manuscript.

Funding: This research received no external funding.

Institutional Review Board Statement: Not applicable.

Informed Consent Statement: Not applicable.

Data Availability Statement: Data are available in the cited literature.

Conflicts of Interest: The authors declare no conflict of interest.

\section{References}

1. Buck, L.B. Unraveling the Sense of Smell (Nobel Lecture). Angew. Chem. Int. Ed. 2005, 44, 6128-6140. [CrossRef] [PubMed]

2. Gainetdinov, R.R.; Hoener, M.C.; Berry, M.D. Trace Amines and Their Receptors. Pharmacol. Rev. 2018, 70, 549-620. [CrossRef]

3. Baly, C.; Aioun, J.; Badonnel, K.; Lacroix, M.-C.; Durieux, D.; Schlegel, C.; Salesse, R.; Caillol, M. Leptin and its receptors are present in the rat olfactory mucosa and modulated by the nutritional status. Brain Res. 2007, 1129, 130-141. [CrossRef]

4. Martin, B.; Maudsley, S.; White, C.M.; Egan, J.M. Hormones in the naso-oropharynx: Endocrine modulation of taste and smell. Trends Endocrinol. Metab. 2009, 20, 163-170. [CrossRef]

5. Kuboki, A.; Kikuta, S.; Otori, N.; Kojima, H.; Matsumoto, I.; Reisert, J.; Yamasoba, T. Insulin-Dependent Maturation of Newly Generated Olfactory Sensory Neurons after Injury. Eneuro 2021, 8, 0168-21.2021. [CrossRef]

6. Caldwell, J.; Londe, K.; Ochs, S.; Hajdu, Z.; Rodewald, A.; Gebhart, V.; Jirikowski, G. Three steroid-binding globulins, their localization in the brain and nose, and what they might be doing there. Steroids 2019, 142, 48-54. [CrossRef] [PubMed]

7. Maßberg, D.; Hatt, H. Human Olfactory Receptors: Novel Cellular Functions Outside of the Nose. Physiol. Rev. 2018, 98, 1739-1763. [CrossRef] [PubMed]

8. Munakata, Y.; Yamada, T.; Imai, J.; Takahashi, K.; Tsukita, S.; Shirai, Y.; Kodama, S.; Asai, Y.; Sugisawa, T.; Chiba, Y.; et al. Olfactory receptors are expressed in pancreatic $\beta$-cells and promote glucose-stimulated insulin secretion. Sci. Rep. 2018, 8, 1499. [CrossRef] [PubMed]

9. Li, E.; Shan, H.; Chen, L.; Long, A.; Zhang, Y.; Liu, Y.; Jia, L.; Wei, F.; Han, J.; Li, T.; et al. OLFR734 Mediates Glucose Metabolism as a Receptor of Asprosin. Cell Metab. 2019, 30,319-328.e8. [CrossRef]

10. Kumarhia, D.; He, L.; McCluskey, L.P. Inflammatory stimuli acutely modulate peripheral taste function. J. Neurophysiol. 2016, 115, 2964-2975. [CrossRef] [PubMed]

11. Kim, L.J.; Polotsky, V.Y. Carotid Body and Metabolic Syndrome: Mechanisms and Potential Therapeutic Targets. Int. J. Mol. Sci. 2020, 21, 5117. [CrossRef]

12. Porzionato, A.; Macchi, V.; De Caro, R.; DI Giulio, C. Inflammatory and immunomodulatory mechanisms in the carotid body. Respir. Physiol. Neurobiol. 2013, 187, 31-40. [CrossRef] [PubMed]

13. Kåhlin, J.; Mkrtchian, S.; Ebberyd, A.; I Eriksson, L.; Fagerlund, M.J. The Human Carotid Body Gene Expression and Function in Signaling of Hypoxia and Inflammation. Adv. Exp. Med. Biol. 2015, 860, 371-377. [CrossRef] [PubMed]

14. Lee, R.; Cohen, N.A. Bitter and sweet taste receptors in the respiratory epithelium in health and disease. J. Mol. Med. 2014, 92, 1235-1244. [CrossRef] [PubMed]

15. Lee, R.J.; Hariri, B.M.; McMahon, D.B.; Chen, B.; Doghramji, L.; Adappa, N.D.; Palmer, J.N.; Kennedy, D.W.; Jiang, P.; Margolskee, R.F.; et al. Bacterial d-amino acids suppress sinonasal innate immunity through sweet taste receptors in solitary chemosensory cells. Sci. Signal. 2017, 10, 7703. [CrossRef]

16. Garg, A.; Sui, P.; Verheyden, J.M.; Young, L.R.; Sun, X. Consider the lung as a sensory organ: A tip from pulmonary neuroendocrine cells. Curr. Top. Dev. Biol. 2019, 132, 67-89. [CrossRef] [PubMed]

17. Noguchi, M.; Furukawa, K.T.; Morimoto, M. Pulmonary neuroendocrine cells: Physiology, tissue homeostasis and disease. Dis. Model. Mech. 2020, 13, 046920. [CrossRef]

18. Xu, J.; Yu, H.; Sun, X. Less Is More: Rare Pulmonary Neuroendocrine Cells Function as Critical Sensors in Lung. Dev. Cell 2020, 55, 123-132. [CrossRef] [PubMed]

19. Ting, H.-A.; Von Moltke, J. The Immune Function of Tuft Cells at Gut Mucosal Surfaces and Beyond. J. Immunol. 2019, 202, 1321-1329. [CrossRef]

20. Gribble, F.M.; Reimann, F. Enteroendocrine Cells: Chemosensors in the Intestinal Epithelium. Annu. Rev. Physiol. 2016, 78, 277-299. [CrossRef]

21. Braun, T.; Voland, P.; Kunz, L.; Prinz, C.; Gratzl, M. Enterochromaffin Cells of the Human Gut: Sensors for Spices and Odorants. Gastroenterology 2007, 132, 1890-1901. [CrossRef] [PubMed]

22. Gu, X.; Karp, P.H.; Brody, S.L.; Pierce, R.A.; Welsh, M.; Holtzman, M.J.; Ben-Shahar, Y. Chemosensory Functions for Pulmonary Neuroendocrine Cells. Am. J. Respir. Cell Mol. Biol. 2014, 50, 637-646. [CrossRef]

23. Chang, A.J.; Ortega, F.E.; Riegler, J.; Madison, D.V.; Krasnow, M.A. Oxygen regulation of breathing through an olfactory receptor activated by lactate. Nat. Cell Biol. 2015, 527, 240-244. [CrossRef] 
24. Lechien, J.R.; Chiesa-Estomba, C.M.; Vaira, L.A.; De Riu, G.; Cammaroto, G.; Chekkoury-Idrissi, Y.; Circiu, M.; Distinguin, L.; Journe, F.; de Terwangne, C.; et al. Correction to: Epidemiological, otolaryngological, olfactory and gustatory outcomes according to the severity of COVID-19: A study of 2579 patients. Eur. Arch. Oto-Rhino-Laryngol. 2021, 278, 1. [CrossRef] [PubMed]

25. Meng, X.; Deng, Y.; Dai, Z.; Meng, Z. COVID-19 and anosmia: A review based on up-to-date knowledge. Am. J. Otolaryngol. 2020, 41, 102581. [CrossRef]

26. Mucignat-Caretta, C.; Bisiacchi, P.; Marcazzan, G.L.; Calistri, A.; Parolin, C.; Antonini, A. TaSCA, an Agile Survey on Chemosensory Impairments for Self-Monitoring of COVID-19 Patients: A Pilot Study. Front. Neurol. 2021, 12, 633574. [CrossRef] [PubMed]

27. Parma, V.; Ohla, K.; Veldhuizen, M.G.; Niv, M.Y.; Kelly, C.E.; Bakke, A.J.; Cooper, K.W.; Bouysset, C.; Pirastu, N.; Dibattista, M.; et al. More Than Smell-COVID-19 Is Associated With Severe Impairment of Smell, Taste, and Chemesthesis. Chem. Senses 2020, 45, 609-622. [CrossRef]

28. Welge-Lüssen, A.; Wolfensberger, M. Olfactory Disorders following Upper Respiratory Tract Infections. Tast. Smell 2006, 63, 125-132. [CrossRef]

29. Lyons-Warren, A.M.; Herman, I.; Hunt, P.J.; Arenkiel, B.R. A systematic-review of olfactory deficits in neurodevelopmental disorders: From mouse to human. Neurosci. Biobehav. Rev. 2021, 125, 110-121. [CrossRef]

30. Walker, I.M.; Fullard, M.E.; Morley, J.F.; Duda, J.E. Olfaction as an early marker of Parkinson's disease and Alzheimer's disease. Handb. Clin. Neurol. 2021, 182, 317-329. [CrossRef] [PubMed]

31. Spotten, L.E.; Corish, C.; Lorton, C.M.; Dhuibhir, P.M.U.; O’Donoghue, N.C.; O'Connor, B.; Walsh, T.D. Subjective and objective taste and smell changes in cancer. Ann. Oncol. 2017, 28, 969-984. [CrossRef]

32. Catamo, E.; Tornese, G.; Concas, M.P.; Gasparini, P.; Robino, A. Differences in taste and smell perception between type 2 diabetes mellitus patients and healthy controls. Nutr. Metab. Cardiovasc. Dis. 2020, 31, 193-200. [CrossRef]

33. Liu, Y.-H.; Huang, Z.; Vaidya, A.; Li, J.; Curhan, G.; Wu, S.; Gao, X. A longitudinal study of altered taste and smell perception and change in blood pressure. Nutr. Metab. Cardiovasc. Dis. 2018, 28, 877-883. [CrossRef]

34. Cecchetto, C.; Di Pizio, A.; Genovese, F.; Calcinoni, O.; Macchi, A.; Dunkel, A.; Ohla, K.; Spinelli, S.; Farruggia, M.C.; Joseph, P.V.; et al. Assessing the extent and timing of chemosensory impairments during COVID-19 pandemic. Sci. Rep. 2021, 11, 1-12. [CrossRef]

35. Hopkins, C.; Watson, D.L.B.; Kelly, C.; Leary, V.; Smith, B.C. Managing long COVID: Don't overlook olfactory dysfunction. BMJ 2020, 370, m3736. [CrossRef] [PubMed]

36. Simonson, T.S.; Baker, T.L.; Banzett, R.B.; Bishop, T.; Dempsey, J.A.; Feldman, J.L.; Guyenet, P.G.; Hodson, E.J.; Mitchell, G.S.; Moya, E.A.; et al. Silent hypoxaemia in COVID-19 patients. J. Physiol. 2021, 599, 1057-1065. [CrossRef] [PubMed]

37. Gonzalez, C.; Conde, S.V.; Gallego-Martín, T.; Olea, E.; Gonzalez-Obeso, E.; Ramirez, M.; Yubero, S.; Agapito, M.T.; Gomez-Niño, A.; Obeso, A.; et al. Fernando de Castro and the discovery of the arterial chemoreceptors. Front. Neuroanat. 2014, 8, 25. [CrossRef] [PubMed]

38. Youngson, C.; A Nurse, C.; Yeger, H.; Cutz, E. Oxygen sensing in airway chemoreceptors. Nat. Cell Biol. 1993, 365, $153-155$. [CrossRef] [PubMed]

39. Rhodin, J.; Dalhamn, T. Electron microscopy of the tracheal ciliated mucosa in rat. Z. Zellforsch. Mikrosk. Anat. 1956, 44, 345-412. [CrossRef] [PubMed]

40. Jarvi, O.; Keyrilainen, O. On the cellular structures of the epithelial invasions in the glandular stomach of mice caused by intramural application of 20-methylcholantren. Acta Pathol. Microbiol. Scand. Suppl. 1956, 39, 72-73. [CrossRef] [PubMed]

41. Saunders, C.J.; Christensen, M.; Finger, T.; Tizzano, M. Cholinergic neurotransmission links solitary chemosensory cells to nasal inflammation. Proc. Natl. Acad. Sci. USA 2014, 111, 6075-6080. [CrossRef] [PubMed]

42. Guan, W.-J.; Ni, Z.-Y.; Hu, Y.; Liang, W.-H.; Ou, C.-Q.; He, J.-X.; Liu, L.; Shan, H.; Lei, C.-L.; Hui, D.S.C.; et al. Clinical Characteristics of Coronavirus Disease 2019 in China. N. Engl. J. Med. 2020, 382, 1708-1720. [CrossRef]

43. Fuglebjerg, N.J.U.; Jensen, T.; Hoyer, N.; Ryrsø, C.K.; Lindegaard, B.; Harboe, Z.B. Silent hypoxia in patients with SARS CoV-2 infection before hospital discharge. Int. J. Infect. Dis. 2020, 99, 100-101. [CrossRef] [PubMed]

44. Archer, S.L.; Sharp, W.W.; Weir, E.K. Differentiating COVID-19 Pneumonia From Acute Respiratory Distress Syndrome and High Altitude Pulmonary: EdemaTherapeutic Implications. Circulation 2020, 142, 101-104. [CrossRef] [PubMed]

45. Gattinoni, L.; Coppola, S.; Cressoni, M.; Busana, M.; Rossi, S.; Chiumello, D. COVID-19 Does Not Lead to a "Typical” Acute Respiratory Distress Syndrome. Am. J. Respir. Crit. Care Med. 2020, 201, 1299-1300. [CrossRef]

46. Dhont, S.; Derom, E.; Van Braeckel, E.; Depuydt, P.; Lambrecht, B.N. The pathophysiology of 'happy' hypoxemia in COVID-19. Respir. Res. 2020, 21, 1-9. [CrossRef] [PubMed]

47. Silent or 'Happy' Hypoxemia: An Urgent Dilemma for COVID-19 Patient Care. MEDICC Rev. 2020, 22, 85. [CrossRef]

48. UR, A.; Verma, K. Happy Hypoxemia in COVID-19-A Neural Hypothesis. ACS Chem. Neurosci. 2020, 11, 1865-1867. [CrossRef] [PubMed]

49. Nouri-Vaskeh, M.; Sharifi, A.; Khalili, N.; Zand, R.; Sharifi, A. Dyspneic and non-dyspneic (silent) hypoxemia in COVID-19: Possible neurological mechanism. Clin. Neurol. Neurosurg. 2020, 198, 106217. [CrossRef] [PubMed]

50. Czick, M.; Shapter, C.; Shapter, R. COVID's Razor: RAS Imbalance, the Common Denominator Across Disparate, Unexpected Aspects of COVID-19. Diabetes Metab. Syndr. Obesity: Targets Ther. 2020, ume 13, 3169-3192. [CrossRef]

51. Villadiego, J.; Ramírez-Lorca, R.; Cala, F.; Labandeira-García, J.L.; Esteban, M.; Toledo-Aral, J.J.; López-Barneo, J. Is Carotid Body Infection Responsible for Silent Hypoxemia in COVID-19 Patients? Function 2020, 2. [CrossRef] 
52. Porzionato, A.; Emmi, A.; Stocco, E.; Barbon, S.; Boscolo-Berto, R.; Macchi, V.; De Caro, R. The potential role of the carotid body in COVID-19. Am. J. Physiol. Cell. Mol. Physiol. 2020, 319, L620-L626. [CrossRef] [PubMed]

53. Tobin, M.J.; Laghi, F.; Jubran, A. Why COVID-19 Silent Hypoxemia Is Baffling to Physicians. Am. J. Respir. Crit. Care Med. 2020, 202, 356-360. [CrossRef]

54. Sobrino, V.; Annese, V.; Pardal, R. Progenitor Cell Heterogeneity in the Adult Carotid Body Germinal Niche. Adv. Exp. Med. Biol. 2019, 1123, 19-38. [CrossRef] [PubMed]

55. Ortega-Sáenz, P.; López-Barneo, J. Physiology of the Carotid Body: From Molecules to Disease. Annu. Rev. Physiol. 2020, 82, 127-149. [CrossRef]

56. Jetté, M.E.; Clary, M.S.; Prager, J.D.; Finger, T.E. Chemical receptors of the arytenoid: A comparison of human and mouse. Laryngoscope 2020, 130, 423-430. [CrossRef]

57. Tan, Z.-Y.; Lu, Y.; Whiteis, C.A.; Benson, C.J.; Chapleau, M.W.; Abboud, F.M. Acid-Sensing Ion Channels Contribute to Transduction of Extracellular Acidosis in Rat Carotid Body Glomus Cells. Circ. Res. 2007, 101, 1009-1019. [CrossRef]

58. Lötsch, J.; Oertel, B.G.; Felden, L.; Nöth, U.; Deichmann, R.; Hummel, T.; Walter, C. Central encoding of the strength of intranasal chemosensory trigeminal stimuli in a human experimental pain setting. Hum. Brain Mapp. 2020, 41, 5240-5254. [CrossRef]

59. Chandrashekar, J.; Yarmolinsky, D.; von Buchholtz, L.; Oka, Y.; Sly, W.; Ryba, N.J.P.; Zuker, C.S. The Taste of Carbonation. Science 2009, 326, 443-445. [CrossRef] [PubMed]

60. Pardal, R.; Ortega-Sáenz, P.; Durán, R.; López-Barneo, J. Glia-like Stem Cells Sustain Physiologic Neurogenesis in the Adult Mammalian Carotid Body. Cell 2007, 131, 364-377. [CrossRef]

61. Chen, Z.; Zhao, H.; Fu, N.; Chen, L. The diversified function and potential therapy of ectopic olfactory receptors in non-olfactory tissues. J. Cell. Physiol. 2018, 233, 2104-2115. [CrossRef]

62. Bilińska, K.; Jakubowska, P.; Von Bartheld, C.S.; Butowt, R. Expression of the SARS-CoV-2 Entry Proteins, ACE2 and TMPRSS2, in Cells of the Olfactory Epithelium: Identification of Cell Types and Trends with Age. ACS Chem. Neurosci. 2020, 11, 1555-1562. [CrossRef] [PubMed]

63. Schultz, H.D. Angiotensin and carotid body chemoreception in heart failure. Curr. Opin. Pharmacol. 2011, 11, 144-149. [CrossRef]

64. Lambermont, B.; Davenne, E.; Maclot, F.; Delvenne, P. SARS-CoV-2 in carotid body. Intensiv. Care Med. 2021, 47, 342-343. [CrossRef]

65. Gulbransen, B.D.; Clapp, T.R.; Finger, T.E.; Kinnamon, S.C. Nasal Solitary Chemoreceptor Cell Responses to Bitter and Trigeminal Stimulants In Vitro. J. Neurophysiol. 2008, 99, 2929-2937. [CrossRef]

66. Tizzano, M.; Cristofoletti, M.; Sbarbati, A.; Finger, T.E. Expression of taste receptors in Solitary Chemosensory Cells of rodent airways. BMC Pulm. Med. 2011, 11, 3. [CrossRef]

67. Lee, R.; Kofonow, J.M.; Rosen, P.L.; Siebert, A.P.; Chen, B.; Doghramji, L.; Xiong, G.; Adappa, N.D.; Palmer, J.N.; Kennedy, D.W.; et al. Bitter and sweet taste receptors regulate human upper respiratory innate immunity. J. Clin. Investig. 2014, 124, 1393-1405. [CrossRef] [PubMed]

68. Finger, T.E.; Böttger, B.; Hansen, A.; Anderson, K.T.; Alimohammadi, H.; Silver, W.L. Solitary chemoreceptor cells in the nasal cavity serve as sentinels of respiration. Proc. Natl. Acad. Sci. USA 2003, 100, 8981-8986. [CrossRef] [PubMed]

69. Krasteva, G.; Canning, B.J.; Hartmann, P.; Veres, T.Z.; Papadakis, T.; Mühlfeld, C.; Schliecker, K.; Tallini, Y.N.; Braun, A.; Hackstein, H.; et al. Cholinergic chemosensory cells in the trachea regulate breathing. Proc. Natl. Acad. Sci. USA 2011, 108, 9478-9483. [CrossRef] [PubMed]

70. Barham, H.P.; Taha, M.A.; Broyles, S.T.; Stevenson, M.M.; Zito, B.A.; Hall, C.A. Association Between Bitter Taste Receptor Phenotype and Clinical Outcomes Among Patients With COVID-19. JAMA Netw. Open 2021, 4, e2111410. [CrossRef]

71. Lee, R.J.; Cohen, N.A. The Emerging Role of the Bitter Taste Receptor T2R38 in Upper Respiratory Infection and Chronic Rhinosinusitis. Am. J. Rhinol. Allergy 2013, 27, 283-286. [CrossRef]

72. Brann, D.H.; Tsukahara, T.; Weinreb, C.; Lipovsek, M.; Van Den Berge, K.; Gong, B.; Chance, R.; Macaulay, I.C.; Chou, H.-J.; Fletcher, R.B.; et al. Non-neuronal expression of SARS-CoV-2 entry genes in the olfactory system suggests mechanisms underlying COVID-19-associated anosmia. Sci. Adv. 2020, 6, eabc5801. [CrossRef] [PubMed]

73. Huart, C.; Philpott, C.; Konstantinidis, I.; Altundag, A.; Whitcroft, K.; Trecca, E.; Cassano, M.; Rombaux, P.; Hummel, T. Comparison of COVID-19 and common cold chemosensory dysfunction. Rhinol. J. 2020, 58, 623-625. [CrossRef]

74. Moein, S.T.; Hashemian, S.M.; Mansourafshar, B.; Khorram-Tousi, A.; Tabarsi, P.; Doty, R.L. Smell dysfunction: A biomarker for COVID-19. Int. Forum Allergy Rhinol. 2020, 10, 944-950. [CrossRef] [PubMed]

75. Seden, N.; Yiğit, E.; Yiğit, Ö.; Kaygısız, I. Objective evaluation of odor loss in COVID-19 and other suspected cases. Am. J. Otolaryngol. 2021, 42, 102761. [CrossRef] [PubMed]

76. Chua, T.P.; Coats, A.J.S. The reproducibility and comparability of tests of the peripheral chemoreflex: Comparing the transient hypoxic ventilatory drive test and the single-breath carbon dioxide response test in healthy subjects. Eur. J. Clin. Investig. 1995, 25, 887-892. [CrossRef] [PubMed]

77. Pfoh, J.R.; Tymko, M.M.; Abrosimova, M.; Boulet, L.M.; Foster, G.E.; Bain, A.R.; Ainslie, P.N.; Steinback, C.D.; Bruce, C.D.; Day, T.A. Comparing and characterizing transient and steady-state tests of the peripheral chemoreflex in humans. Exp. Physiol. 2016, 101, 432-447. [CrossRef] 
78. ATS Committee on Proficiency Standards for Clinical Pulmonary Function Laboratories. ATS Statement: Guidelines for the six-minute walk test. Am. J. Respir. Crit. Care Med. 2002, 166, 111-117. [CrossRef] [PubMed]

79. Pandit, R.; Vaity, C.; Mulakavalupil, B.; Matthew, A.; Sabnis, K.; Joshi, S. Unmasking Hypoxia in COVID 19-Six Minute Walk Test. J. Assoc. Physicians India 2020, 68, 50-51. [PubMed] 